REPORTS ON RECENT MEETINGS

\title{
Meetings
}

Atlantic Geoscience Society, Review of Activities for 1972 by D.F. CLARK, Atlantic Geoscience Centre, Bedford Institute of Oceanography, Dartmouth, N.S.

The Atlantic Geoscience Society is an organization which was formed to promote the geosciences within the Atlantic Provinces of Canada and to improve the communications between the 12 active geoscience centres in the area.

The Society was the first attempt at providing a forum for individuals to gather together on a regular but informal basis for the purpose of exchanging opinions and developing new ideas.

The inaugural meeting was held on May 31, 1972 at Dalhousie University Faculty Club. The guest speaker was Mr. D.F. Sherwin of the federal Department of Energy, Mines and Resources. He gave a liberally illustrated talk on the stratigraphy of the Eastern Continental Shelf of Canada and discussed the oil potential for the area. An encouraging 90 people were present, including some from Newfoundland and New Brunswick.

After a summer of planning, the AGS started its fall program with Dr. John Dewey from New York University. Dr. Dewey, well known for his theories on plate tectonics, particularly in the Western Hemisphere, produced an interesting evening for the large number of people who gathered to listen.

The November meeting was held at Acadia University. Our invited speaker was Dr. N. Rast of U.N.B. Dr. Rast exposed his listeners to some radical ideas on tectonic activities in the southern New Brunwick area during the time of the Hercynian orogeny in western Europe.

Future talks, such as that to be given by Dr. Ward Neale of Memorial University on the economic implications of the tectonic provinces of Newfoundland and that by Dr. John Jones of the N.S. Department of Mines on ground water hydrology in the Antigonish area have the potential for holding the attention of the many varied members of the AGS.

The Executive of the AGS has initiated an experimental Seminar Clearing House program. The goal is to collect and publish all available information on geoscience visitors speaking in the Atlantic Provinces in the upcoming months. Hopefully, this will result in better use of speaker time and encourage larger audience attendance by increased and early publicity.

Colloguium ' 73 - The fall of 1973 will see the first AGS Colloquium. It will be held at the University of New Brunswick. With minimum travelling times and costs, it is hoped that many of the regional geoscientists will be able to discuss ideas and plans for future research.

The meeting will be of three days duration with two days devoted to invited and submitted papers, and the third to a field trip in the saint John area.

1972 Executive of the AGS - The executive is as follows: Chairman, R.H. MacNeill, Acadia University; Vice-Chairman, M.J. Keen, Dalhousie University; Secretary-Treasurer, G.L. Williams, Geological Survey of Canada; Editor, D.F. Clark, Geological Survey of Canada; Council Members:K. Howells, N.S. Research Foundation; M.J. Kennedy, Memorial University; J.P. Nowlan, N.S. Department of Mines; N. Rast, University of New Brunswick; and W.S. Shaw, St. Francis Xavier University.

FORTHCOMING MEETINGS

Society of Economic Paleontologists and Mineralogists, Anheim, California, May 13, 1973.

The S.E.P.M. Research Group on Turbidites and Deep Marine Sedimentation is planning on holding another colloquium, this one in the heart of American turbidite territory, southern California. Besides the colloquium several of the planned activities at the meetings should particularly recommend themselves to this group.

The colloquium will be held from 7:00 p.m. onwards on Sunday, May 13th in Royal Room No. 2, at the Royal Inn, Anaheim. It has been scheduled so as not to conflict with two other activities of major interest to the group: the short course on Saturday and the field trip to Upper Newport Bay, Dana Point and Dana Harbour (S.E.P.M. Trip 1) on Sunday morning and afternoon.

We are proposing that the main theme for the colloquium should be: 
"Super-proximal environments: slope and channel deposits"

I have arranged to bring over Dr. Franco Ricci Lucchi, one of the most active Italian workers on these type of deposits. Franco will tour a few universities (who have agreed to finance his visit over), give a formal paper at the S.E.P.M. Session on Turbidites and Deep Marine Sedimentation, to be held Wednesday afternoon, May 16th, and give an informal discussion at our evening colloquium. We also hope to get a short presentation from his fellow countryman, Emiliano Mutti.

So far, no other contributions have been arranged. Do you have a five minute presentation that might stimulate discussion on the theme of submarine debris flows, grain flows or conglomeratic turbidites? Do you have the definitive criteria for slope deposits or the true interpretation of dish structure? If you do have, write and let me know and I will put you on the program.

S.E.P.M. Short Course on Turbidites and Deep Water Sedimentation -

This course has been organized for S.E.P.M. by Drs. A.H. Bouma and G.V. Middleton. It has been designed as a "refresher" course for professional geologists whose duties or principal interest have prevented them from following in detail the major developments in the concepts of turbidity currents and deep water sedimentation that have taken place in the last 10 years.

Therefore, we are not urging the distinguished members of this group to attend themselves. But how about their graduate students? Or their colleagues who are teaching (for example) stratigraphy or carbonate petrology and want to catch up on the latest developments outside their field of specialization in the least painful way?

We do urge you to support this short Course, not only because our personal neck is on the block, but because this is the first Short Course ever organized by S.E.P.M. S.E.P.M.-A.A.P.G may lose interest in future courses if this one does not sell out (registration is restricted to 120 persons). The organization of the course is new: four groups of two instructors each have agreed to teach the course for no fee (even the expenses are not guaranteed). The total group of 120 will be divided into four groups of 30 each, so that there will be plenty of opportunity for discussion and personal contact between instructor and participant.

You can also support the course by ordering a copy of the course notes, written by A.H. Bouma, M. Hampton, L.D. Kulm, G.V. Middleton, E. Mutti, C.H. Nelson and R.G. Walker. Price $\$ 5.00$.

Field trips - The Sunday field trip (S.E.P.M. Trip 1) "Miocene Sedimentary Environments and Biofacies, Southeastern Los Angeles Basin" should be of special interest to all members of this research group. Sign up for this trip, see the new exposures of the famous Doheny Channel (and much, much more) and hear the latest interpretations from J.C. Ingle, W.W. Wornardt, R.S. Yeats, C.J. Stuart, A.D. Warren, W.R. Normark and J.A. Bartow.

Session - This should be a bumper meeting for members of this research group, with the S.E.P.M. Research Symposium devoted to Tectonics and Sedimentation (Tuesday, May 15) and a S.E.P.M. session on Turbidites and Deep Marine Sedimentation on Wednesday afternoon.

G.A.C. Flysch volume - While I am in the advertising business I cannot resist adding a note about the Geological Association of Canada Special Paper 7, "Flysch Sedimentology in North America", edited by J. Lajoie (1970). Copies of this volume are still available at a price of $\$ 12.00$ from Business and Economic Service Ltd., 111 Peter Street, Toronto, Ontario, Canada. This is still the single most comprehensive and up-to-date review of the topic.

G.V. MIDDLETON

McMaster University, Hamilton, Ontario

\section{Additional notes:}

The course will be given from $10 \mathrm{a} . \mathrm{m}$. to $5 \mathrm{p} . \mathrm{m}$. on Saturday, May 12, 1973, in the Disneyland Hotel, Anaheim, California. Enrolment will be limited to 120, and participants will be divided into four groups, so that there will be ample opportunity for contact and discussion between participants and course instructors. Each group will spend a 90 minute period on each of four major aspects of the subject: (1) Mechanics of flow and deposition, (2) Submarine fans and channels, (3) Basin (distal) sediments, (4) Facies models for turbidite basins. Instructors for the four sections will include G.V. Middleton (McMaster University), M. Hampton (University of Rhode Island), C.H. Nelson (U.S.G.S., Menlo Park), A.H. Bouma (Texas A and M University), C.D. Hollister (Woods Hole Oceanographic Lab.) and R.G. Walker (McMaster University). Registration fee for the course is $\$ 20$. and includes a copy of a volume of notes prepared especially for this course.

Questions discussed will include: What are turbidity currents and how do they form and move? How is sediment deposited by them? What other mechanisms are responsible for depositing sediment 
in deep water? What have oceanographic studies (including deep sea drilling and seismic profiling) revealed about the characteristics of deep sea channels, fans and basins? How can we recognize ancient sediments deposited in these environments? What do facies models based on these studies tell us about the geometry of the sandstone bodies?

For those interested please contact Dr. John R. Castano, Shell Oil Company, 1008 West Sixth Street, Los Angeles, California, U.S.A.

Joint Meeting of Geological Association of Canada, Alberta Society of Petroleum Geologists and Mineralogical Association of Canada, Saskatoon, Sask., May 23-26, 1973.

Technical Sessions:

1. Symposium on the Geology of the Canadian Arctic:- Sponsored by the Geological Association of Canada and the Alberta Society of Petroleum Geologists, and incorporating the Fifth Canadian Conference on Research in Tectonics. All aspects of the geology of the Canadian Arctic and surrounding regions will be considered. The proceedings will be published in a special volume by the Geological Association of Canada and the Alberta Society of Petroleum Geologists. A preconference field trip to the western Arctic will be offered.

2. Colloquium on the Cretaceous System in the Western Interior of North America:- Sponsored by the Geological Association of Canada. The Colloquium will emphasize two broad aspects of the Cretaceous System in the western Interior of North America, (i) biostratigraphy, and (ii) deltaic sedimentology, but will also include topics dealing with other aspects of the stratigraphy of Cretaceous strata in the Western Interior. The proceedings will be published by the Geological Association of Canada in its Special Papers series.

3. Geological Association of Canada Annual Meeting:- Papers dealing with all aspects of geology and geophysics other than those covered by the Arctic symposium and the Colloquium on the Cretaceous System will be considered.

4. Mineralogical Association of Canada Annual Meeting:- Two technical sessions will be held, (i) a general conference on mineralogy and on chemical aspects of petrology, and (ii) a special session on the mineralogy and geochemistry of sedimentary rocks and their implications for exploration.

Field Trips in Saskatchewan, sponsored by the Saskatchewan Geological Society:

Pre-Convention

A) Lignites of the Estevan Area (May 23). Leader: P. Guliov. Stratigraphy and exploitation of Lower Tertiary coal deposits.

B) Cretaceous Stratigraphy in the Avonlea-Big Muddy Valley Area (May 23). Leaders: I. Vigrass and D. Kent. Stratigraphy of Upper Cretaceous and Lower Tertiary deposits and examination of icethrust structures in the Missouri Coteau.

C) Pleistocene Geology in the Saskatoon-Qu'Appelle Valley - Regina Area (May 22-23). Leader: E. Christiansen. Pleistocene stratigraphy and land forms, with emphasis on the history of deglaciation. A volcanic ash and several vertebrate fossil localities will be visited.

D) Northern Saskatchewan Uranium Tour. Leaders: A.J. Gracie and T.H. de Zoysa. Examination of mineralized core at the DMR laboratory in La Ronge; visit to the Rabbit Lake orebody, the Ace-Fay mine and mill, surface geology and uranium showings in the Beaverlodge area, and surface showings and drill core in the Carswell Lake area (Mokta camp).

Post-Convention

E) Cretaceous Startigraphy of the Swift Current-Cypress Hills Area (May 27-28). Leaders: S.H. Whitaker and J.A. Vonhof. Upper Cretaceous and Lower Tertiary stratigraphy, with principal emphasis on the south flank of the Cypress Hills.

F) Roadside Geology (mainly Precambrian) between La Ronge and Reindeer Lake (May 27-29). Leader: L. Forsythe. Meta-volcanic and meta-sedimentary rocks, complexly folded metamorphic rocks, and intrusive complexes. Brief tour of the Anglo-Rouyn Copper Mine.

G) Geology of the Hanson Lake Road-Flin Flon Area (May 27-29). Leaders: J. Christopher, D. Kent and M. Stauffer. Brief examination of Pleistocene land forms and stratigraphy. Ordovician carbonates and Precambrian metamorphic rocks along the Hanson Lake Road. Three optional half-day trips are offered: (a.m., May 28):

Option Gl -- Precambrian volcanic and intrusive rocks in the vicinity of Flin Flon. 
Option G2 -- Ordovician-Silurian stratigraphy at Namew Lake, south of Flin Flon (travel by aircraft).

Option G3 -- Tour of HBM \& S Co. Ltd. copper and zinc mine.

All options will combine for a half day (p.m. May 28) examination of the stratigraphy and structure of the Missi Group of metaconglomerates and sandstones in and around Flin Flon.

Field Trip to the Western Arctic (May 21-22). Leader: H.R. Hovdebo.

First day: Calgary-Fort Nelson, over Mackenzie-Ogilvie-British Mountains to Inuvik.

Second day: Inuvik, over Richardson Mtns., Peel Plateau to Norman Wells; pass Franklin Mtns., and return to Saskatoon on evening of May 22. Overnight stay at Inuvik.

Remote Sensing of Water Resources International Symposium, Canada Centre for Inland Waters, Burlington, Ont., June $11-14,1973$.

The American Water Resources Association and the Canada Centre for Inland Waters announce an International symposium on the Remote Sensing of Water Resources, a symposium on the applications of remote sensing to water resources management. Emphasis will be placed on those studies which show definitive interpretations of water quality and quantity, or related environmental aspects. Papers concerned with the following topics are invited.

A. Water Resources Applications of Airborne Remote Sensing:
Water Quality Aspects

Water Quantity Aspects

B. Water Resources Applications of Satellite-borne Sensors: Water Quality Aspects

Water Quantity Aspects

C. The Role of Remote Sensing in Integrated Water Resources Management Systems: Managing for Quality Managing for Quantity Specific Examples of the Role of Remote Sensing in Integrated Water Resources Management Systems

Dr. Robert Iane (General Chairman), Head, Iake Resources Subdivision, Canada Centre for Inland waters, P.O. Box 5050, Burlington, Ontario, Canada.

Earth Science Summer Workshop for Teachers Funded by Shell Canada to be held at the University of Western Ontario, London, Ont., July 1973 .

The Earth Science Workshop for secondary and senior elementary school teachers was held in the Department of Geology, University of Western Ontario, during July 1972. Eighteen participants from Ontario, Quebec and Saskatchewan were selected. The course instructors were Ontario school teachers, - Nelson Stroud, geology graduate from Waterloo and Howard Cramer, a specialist in outdoor education.

The curriculum developed by Western faculty and the instructors was presented as lectures and laboratories with substantial modification from E.S.C.P. from which laboratories exercises were utilized. Three field sessions to the Precambrian at Sudbury, the Paleozoic across Southern Ontario and the Pleistocene around London, conducted by R.W. Hutchinson, C.G. Winder and A. Dreimanis, constituted about one third of the course. The trips provided the opportunity to gain an understanding of the expanse of geological time, collect representative suites of rocks and take pictures of typical and special rock features.

Special lectures were given by Dr. Robert Legget, Ottawa, on environment problems and Mr. Edward Freeman, Ministry of Natural Resources, Toronto, sources of earth science literature and materials.

During the last three years, financial support for the workshop has been supplied by the Canadian Geological Foundation, INCO, the Geological Survey of Canada along with special concessions on supplies and books by Thomas Nelson \& Co., Stark Electronics, and others. Beginning in 1973 and for a period of three years, the Workshop will receive full financial support from Shell Canada Limited. The twenty selected teachers will be provided with return transportation to London, accommodation and meals in the University residence, and all expenses on field trips along with necessary field equipment. Teachers from across Canada will be urged to apply and the selected group will include individuals from every province and territory, provided certain standards are met. The course does not provide university credit, a policy endorsed by previous 
participants.

The Shell Canada Earth Science Workshop for 1973 will be held at western in London during July. Individuals who wish to apply or who know a teacher worthy of recomendation, should request the application forms from the Director of Summer School and Extension, University of Western Ontario, London.

The Fourth International Working-Meeting on soil Micromorphology to be held at Queen's University, Kingston, Ont., August 27-31, 1973.

The purpose of the working-Meeting is to bring together workers in soil and sedimentary micromorphology from a number of different disciplines to discuss their involvement with the various aspects of the broad field of soil and sedimentary micromorphology. This field encompasses areas of interest which include agriculture, paleopedology, foundation engineering, erosion, weathering, experimental pedology, sedimentology, waste disposal, etc.

With the ever-increasing range of techniques available to the micromorphologist and the wider interest in this field, the need for communication and an understanding of the ramifications of the recent developments within the discipline becomes obvious.

The Working-Meeting is being sponsored by The Department of Geography of Queen's University and support is being canvassed from the National Research Council of Canada, The Canada Department of Agriculture and The Canadian Society of Soil Science.

Already some sixty titles covering a wide range of topics have been received from prospective participants. In addition to sessions for papers on soil genesis and properties, there are sufficient papers for sessions on the Scanning Electron Microscope, applied micromorphology, soil mechanics and recent technological developments in micromorphology.

The organizing committee is very desirous of attracting further papers particularly in the microscopy of sediments and deep soil horizons, micromorhpometry, and the computerization of micromorphology. Kindly send all manuscripts to the secretary before June 1, 1973. Russian):

All enquiries should be addressed to the organizer (in English, French, German, Spanish or

Prof. G.K. Rutherford, Department of Geography, Queen's University, Kingston, Ontario, Canada.

Ist Symposium on the Geological Action of Drift Ice, Quebec City, Que., April 20-24, 1974.

The first symposium on the geological action of drift ice (lake, fluvial, shore and marine ice) will be held in Quebec City, April 20-24, 1974. A three-day paper session and a two-day field trip are planned. Quebec.

The meeting is sponsored by the Institut National de la Recherche Scientifique (INRS,

Papers covering the various geological aspects of drift ice (erosion, transportation, sedimentation, protection) within the following environments are requested: Coastal and estuarine; Marine: offshore, sheld, and deep-sea; Lacustrine; and Fluvial and deltaic.

\section{Main Subjects to be Discussed:}

Geological action of drift ice: erosion, transportation, sedimentation, protection; world geographical limits of drift ice action during the Quaternary and today; The icefoot: definition, characteristics, classification, geological action; Processes incorporating sediments into drift ice; Action of ice in tidal flats environments; Action of ice in the development of cold regions beaches; Action of ice on the bottom of shallow seas and lakes; Action of ice on rocky shores; Geological action of icebergs; Deformational structures produced by drift ice and icebergs; Characteristics of drift ice sediments; Ice-rafted sediments and features in Pleistocene deposits; Ice-rafted sediments and features in consolidated rocks; Action of drift ice upon the biological environment; Practical aspects of drift ice in coastal and marine engineering and Drift ice terminology.

Abstracts should be sent before January 1, 1974 to:

Dr. Jean-Claude Dionne, Environment Canada, C.P. 3800, Sainte-Foy, Quebec, Canada. 